\title{
Full Cost Vs Successful Efforts Accounting: A Systematic Review
}

Osareme Erhomosele, Lukman Jimoh Rahim

To Link this Article: http://dx.doi.org/10.6007/IJARAFMS/v11-i3/10548 DOI:10.6007/IJARAFMS /v11-i3/10548

Received: 03 June 2021, Revised: 07 July 2021, Accepted: 30 July 2021

Published Online: 15 August 2021

In-Text Citation: (Erhomosele \& Rahim, 2021)

To Cite this Article: Erhomosele, O., \& Rahim, L. J. (2021). Full Cost Vs Successful Efforts Accounting: A Systematic Review. International Journal of Academic Research in Accounting Finance and Management Sciences, 11(3), 145-156.

\section{Copyright: @ 2021 The Author(s)}

Published by Human Resource Management Academic Research Society (www.hrmars.com)

This article is published under the Creative Commons Attribution (CC BY 4.0) license. Anyone may reproduce, distribute, translate and create derivative works of this article (for both commercial and non-commercial purposes), subject to full attribution to the original publication and authors. The full terms of this license may be seen at: http://creativecommons.org/licences/by/4.0/legalcode

Vol. 11, No. 3, 2021, Pg. 145 - 156 


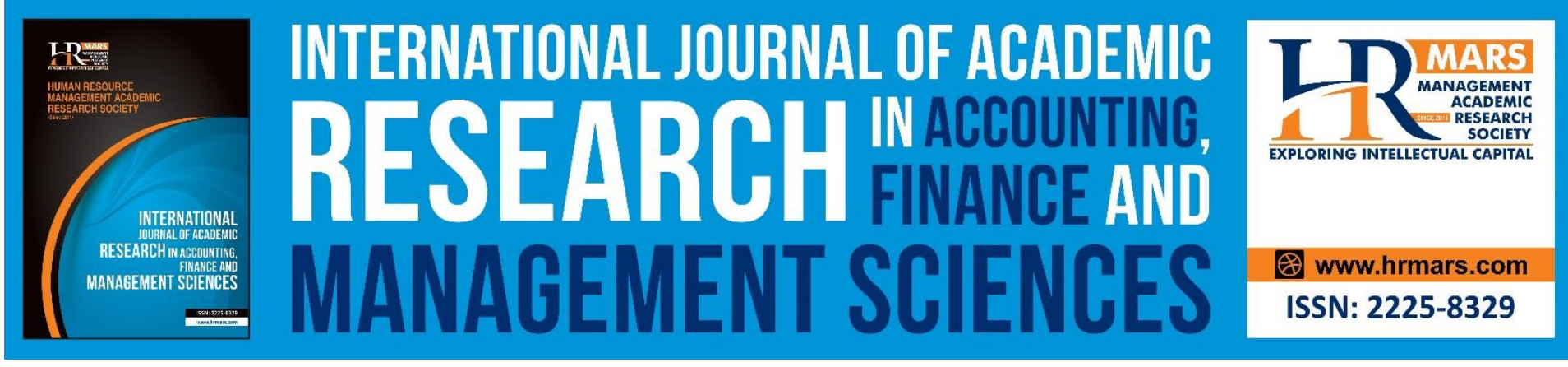

\title{
Full Cost Vs Successful Efforts Accounting: A Systematic Review
}

\author{
Osareme Erhomosele, Lukman Jimoh Rahim \\ Department of Accounting, Faculty of Management Sciences, University of Jos, Nigeria. \\ Email: erhomoseleo@unijos.edu.ng,rahiml@unijos.edu.ng
}

\begin{abstract}
Harmonization of the accounting practice has long been on the front burner as an agenda for improving the quality of financial reporting the world over. This study is a qualitative review of the Full cost (FC) and Successful efforts (SE) methods of accounting in the oil and gas sector, given the ongoing controversy over which method should take precedence. A unique analysis was adopted by assessing the merits and demerits of the FC and SE methods based on selected qualitative criteria (conceptual, IASB framework and industry-specific). The study found significant differences between the two methods and argues that the SE method produces better qualitative financial information than the FC method based on the IASB framework criteria. The study also found low-risk exposure in Nigeria for investors in the oil and gas industry as a majority of the oil and gas firms operate within the downstream sector. Further research is required to determine the long-run impact of the choice between FC and SE on the performance of oil and gas firms.
\end{abstract}

Keywords: Oil and Gas, Full Cost, Successful Efforts, Accounting Choice Theory, Harmonization, IASB

\section{Introduction}

Oil and gas have been a major source of power and energy globally. This natural resource has shaped the world in more ways than one. It has proven significant, both on political and economic fronts; albeit, having both positive and negative implications. Within the Nigerian context, oil has been the mainstay of the economy since its discovery in 1956, playing a fundamental role in the economic life of the country (Obara \& Nangih, 2017). This allimportant role suggests that deliberate attention must be paid to the operations and activities of the oil and gas sector, also known as the petroleum industry. There is a need to account for oil and gas reserves to enable participants in the industry to maximize the benefits derivable from such a natural endowment. Strangely, however, in spite of the metamorphosis experienced in the oil and gas industry over the years, the world over, standard-setting for oil and gas has been an area of controversy since time immemorial (Umobong, 2015; Abushaiba \& Eldanfo, 2014).

The American Institute of Certified Public Accountants (AICPA) has defined accounting as the art of recording, classifying and summarizing in a significant manner and in terms of money, transactions and events which are, in part at least, of financial character and interpreting the 
MANAGEMENT SCIENCES

Vol. 11, No. 3, 2021, E-ISSN: 2225-8329 @ 2021 HRMARS

results thereof. Indeed, accounting has been described as the language of business throughout the world. Prospecting for oil and gas is big business, which involves huge capital investment, enormous risk and the promise of high but volatile returns. All these characteristics clearly indicate the fundamental role of accounting in oil and gas operations. This paper is concerned with the accounting treatment required at the exploration phase of oil and gas operations. It is at the exploration phase that companies have a choice between alternative accounting methods, thus raising questions as to which accounting choice is the most appropriate. There are basically two accounting methods used at this stage of oil and gas accounting; the Successful efforts method (SE) and the Full cost method (FC) (Kaoje, Sa'ad, Abubakar, \& Bala, 2016).

A brief adventure into the history of this controversy reveals that the SE method was the only method initially used prior to the late 1950s and early 1960s. However, with no explicit accounting code or regulation for the extractive industry at the time, the FC method emerged in the late 1950s. Belco Petroleum was the first company to deploy the FC method in 1957. In July 1977, the Financial Accounting Standards Board (FASB) was first to respond to calls for a single standard to be applied by petroleum companies. It issued the Statement of Financial Accounting Standard No. 19 (SFAS 19) in December 1977. SFAS 19 proposed the adoption of a single standard based on the concept of the successful effort. Deakin (1979) noted that there was unprecedented opposition to SFAS 19 by full cost companies, backed up by appeals that the standard be repealed. The backbone of the argument put forward by full cost companies was that there were fundamental differences between entities using each accounting method, thus, a justification for maintaining the status quo. According to Deakin (1979), these differences are highlighted by the arguments of full cost companies related specifically to; (i) aggressiveness in exploration, (ii) the need for external capital, (iii) company size, and (iv) age of the company. Such was the intensity of opposition that the United States Securities and Exchange Commission (SEC) reversed its initial decision to adopt SFAS 19. The SEC eventually took a policy stand to permit both the SE and FC methods. It however proposed a third method which is referred to as Reserve Recognition Accounting (RRA) (Kaoje et al., 2016). The RRA was to deal with the inefficiency of historical accounting (SE and FC) methods in accounting for oil and gas operations (Luther, 1996).

The International Accounting Standards Board (IASB) has made very little contribution to the oil and gas discussion, save its issuance of International Financial Reporting Standard (IFRS) 6_ (Exploration for and evaluation of mineral resources) in 2004. Once again, intense lobbying by vested interests ensured that IFRS 6 maintained the status quo (Nichols, 2012; Brown, 2006). IFRS 6 provides guidance on financial reporting for exploration and evaluation (E\&E) expenditures, yet it is silent on the controversy between SE and FC methods of accounting for such expenditures. On the Nigerian front, the Nigerian Accounting Standards Board (NASB) had issued local standards to cater for petroleum operations in the absence of a specific standard to that effect by the IASB. While the Statement of Accounting Standard (SAS) 14 Accounting in the Petroleum industry- upstream activities was to cater for upstream oil and gas operations, the Statement of Accounting Standard (SAS) 17_Accounting in the Petroleum industry- downstream activities was issued in respect of downstream petroleum operations. These local accounting standards also failed to discriminate between the SE and FC methods of accounting. Thus, standardization remains elusive (Luther, 1996) and the controversy lives on to this day.

While this paper is contextual, relating to oil and gas operations within Nigeria. It is important to note that a bulk of the oil and gas operations in Nigeria is carried on by multinational oil 
MANAGEMENT SCIENCES

Vol. 11, No. 3, 2021, E-ISSN: 2225-8329 @ 2021 HRMARS

companies. Thus, the implication of this is that the issue of accounting choice between the SE and FC methods is one of a global prevalence and unlikely to be influenced by country specifics.

\section{Significance of the Study}

There is currently no consensus on the choice of accounting method to be applied by oil and gas firms in the upstream sector. While both the Successful efforts and Full cost methods are permissible in most climes around the world, including Nigeria; the debate continues as to which method is more appropriate in communicating both conceptual and practical realities, to enable users make informed judgements and decisions based on the results of operations as contained in the financial statements. This dilemma can be attributed to the unique and complex nature of the oil and gas business and the potential interference of vested interests in the standard setting process.

There is also a concern as to the nature and extent to which a choice between the full cost and successful effort methods affects the performance and state of affairs of the firm. The net effect of permitting both methods of accounting is that it hampers comparability and possibly relevance, as well as, faithful presentation of financial statements; thus, creating some form of dilemma especially for investors who are unable to effectively make parallel comparisons between the performance of full cost and successful efforts companies.

\section{Study Objectives}

The focus of this study is to review the ongoing controversy between the Successful Efforts method and the Full cost methods. This is significant in the light of the FASB's initial stand that the successful efforts method was the most appropriate method, as proposed in SFAS 19 (Deakin , 1979). The study will attempt to summarize the arguments from literature which may prove to be a resource from which the IASB can draw, as it seeks to issue future guidance for financial reporting in the extractive industry. An attempt is made to answer the following research questions:

i. What are the salient differences between the SE and FC accounting methods?

ii. Which is the more appropriate method with recourse to the prevailing GAAP in Nigeria?

iii. To what extent are investors in the Nigerian oil and gas industry exposed to risk occasioned by the choice between SE and FC accounting methods?

\section{Concept of Oil and Gas Operations}

Oil and gas operations are generally classified as either upstream, midstream or downstream (Institute of Chartered Accountants of Nigeria, 2014). Upstream activities generally refer to operations required to search for and recover and raw oil and gas from within the earth's crust to the surface. Midstream consists of activities carried out to prepare oil and gas produced from upstream operations for the downstream phase. The Downstream sector ensures that crude oil and natural gas is made available to consumers for use. Classification of oil and gas operations is significant for accounting purposes. This is because specialized accounting and financial reporting rules and standards apply differently across the various classifications. This is also true in respect of relevant tax regimes.

Exploration costs, which has been highlighted as being significant in this study, refers to costs related to the collection and analysis of geophysical and seismic data required for determining the viability of a targeted area, for the purpose of deciding if such an area should 
MANAGEMENT SCIENCES

Vol. 11, No. 3, 2021, E-ISSN: 2225-8329 @ 2021 HRMARS

be developed (Umobong, 2015). Exploration costs could be classified as either (i) intangible: cost incurred to ready a target area for installation of drilling equipment; or (ii) tangible: costs directly incurred on installing and operating equipment to be used for drilling. Other costs incurred in the upstream phase of oil and gas operations include acquisition, development and production costs. Participants in the oil and gas industry in Nigeria are mainly the Nigerian National Petroleum Corporation (NNPC) and international and local oil companies. These companies are responsible for preparing and presenting financial reports about their operations.

Local oil companies registered in Nigeria are required by the Companies and Allied Matters Act (CAMA) to publish their financial statements if they are publicly traded entities. They must also adhere to the Nigerian Securities and Exchange Commission (SEC) rules for financial reporting as a requirement for listing on the Exchange. Multinational oil companies are mostly listed on the stock exchanges of their home countries. However, such companies usually prepare accounting reports for tax purposes and in respect of contractual obligations to the NNPC.

\section{Full Cost Method (FC) vs Successful Efforts Method (SE)}

The fundamental difference between the SE and FC is in the treatment of incurred exploration costs that do not result in the discovery of oil or gas reserves. Table 1 shows that while such costs are capitalized under the full cost method; the successful effort method, on the other hand, requires that such costs be expensed. Capitalization implies that such cost will be written off periodically either through abandonment, Impairment, or depletion as reserves to which the cost relates is continually exploited. Conversely, expensing cost of exploratory dry well requires such cost to be charged against revenue in the current period.

Table 1: comparison of successful efforts method with full cost method

\begin{tabular}{lcl}
\hline Item & Successful efforts & Full cost \\
\hline Acquisition costs & Capitalize & Capitalize \\
G\&G costs* & Expense & Capitalize \\
Exploratory dry well & Expense & Capitalize \\
Exploratory well, successful & Capitalize & Capitalize \\
Development dry hole & Capitalize & Capitalize \\
Development well, successful & Capitalize & Capitalize \\
Production costs & Expense & Expense \\
Amortization cost center & Property, field or reservoir & Country \\
\hline
\end{tabular}

Source: (Wright \& Gallun, 2008) *G\&G: Geological and Geophysical

Another major difference of note between the SE and FC relates to the size of the cost center over which costs are accumulated and amortized. While these accounting methods may seem simplistic conceptually; in practice, however, there are variations in their applications. A quantitative illustration will suffice to show how the concepts of FC and SE operate in practice ${ }^{1}$. Such a hypothetical illustration is also significant to assess the nature of

${ }^{1}$ Illustration provided is an adaptation from a breaking into Wall Street article: Quick Reference - Successful Efforts vs. Full Cost Accounting. Accessed from:

http://breakingintowallstreet.com. 
INTERNATIONAL JOURNAL OF ACADEMIC RESEARCH IN ACCOUNTING, FINANCE AND MANAGEMENT SCIENCES

Vol. 11, No. 3, 2021, E-ISSN: 2225-8329 @ 2021 HRMARS

impact the choice of accounting method may have on the financial results of oil and gas firms operating in Nigeria.

Table 2: Illustrative assumption

Illustration Assumptions

\begin{tabular}{l|c|l|c}
\hline & Million(\#) & & Million(\#) \\
\hline Revenue & 1000 & Production & 150 \\
Property acquisitions & 50 & General and administrative & 50 \\
Dry holes & 200 & DD\&A_Successful & 200 \\
Successful & 100 & DD\&A_Full cost & 300 \\
Development & 200 & Tax rate & $40 \%$ \\
\hline
\end{tabular}

*DD\&A: Depreciation, Depletion and Amortization

The results in table 3 show a much higher DD\&A for the successful efforts method than for the full cost method. The difference is that the Dry Hole Expense for Unsuccessful Exploration is expensed in the Income Statement under the successful efforts method but is capitalized under the full cost method. As a result, full cost companies accrue higher PP\&E balances and therefore have higher Depreciation numbers. Tables 2 and 3 reveal the areas of impact on the financial statements between the SE and FC methods. While an SE Company will record lower net income and net assets in the early years, an FC company will initially record higher net income and net assets, but this will continue to fall over successive periods. Technically, the overall consequence of the difference between the two methods relates merely to the "timing" of profit or loss recognition. However, the issue of timing has grave significance for accounting and financial reporting. Users of financial information make decisions per time after all.

Table 3: Income statement of illustrative assumptions

\begin{tabular}{|c|c|c|c|c|}
\hline \multicolumn{5}{|c|}{ Income statement } \\
\hline \multirow[t]{2}{*}{ Particulars } & \multicolumn{2}{|c|}{$\begin{array}{l}\text { Successful effort } \\
\text { method }\end{array}$} & \multicolumn{2}{|c|}{ Full cost method } \\
\hline & Million(\#) & Million(\$) & Million(\#) & Million(A) \\
\hline Revenue & & 1000 & & 1000 \\
\hline Expenses: & & & & \\
\hline Production & 150 & & 150 & \\
\hline Exploration & 200 & & - & \\
\hline $\begin{array}{l}\text { Depreciation, Depletion \& Amortization } \\
\text { (DD\&A) }\end{array}$ & 200 & & 300 & \\
\hline General and administrative & 50 & $(600)$ & 50 & $(500)$ \\
\hline Operating income & & 400 & & 500 \\
\hline $\begin{array}{l}\text { Income tax expense } \\
\text { Net income }\end{array}$ & & $\frac{(160)}{2100}$ & & $\frac{(\angle 00)}{300}$ \\
\hline Net income & & 240 & & 300 \\
\hline
\end{tabular}


Table 4: Abridged statement of affairs for illustrative assumptions

\begin{tabular}{l|c|c}
\hline \multicolumn{3}{c}{ Statement of affairs } \\
\hline & $\begin{array}{c}\text { Successful } \\
\text { effort method }\end{array}$ & $\begin{array}{c}\text { Full cost } \\
\text { method }\end{array}$ \\
\hline Property acquisitions & $\begin{array}{c}\text { Million(A) } \\
\text { Million(\$) }\end{array}$ & 50 \\
Exploration & 50 & 300 \\
Development & 100 & 200 \\
Depreciation, Depletion \& Amortization (DD\&A) & 200 & $(300)$ \\
\hline Net Property, plant and equipment (PP\&E) & $\mathbf{2 0 0 )}$ & $\mathbf{2 5 0}$ \\
\hline
\end{tabular}

\section{The Accounting Choice Theory}

Considering the controversy between SE and FC methods of accounting, the accounting choice theory seeks to answer the question of whether the choice of accounting method really matters. Accounting choice implies the firm's choice between alternative accounting treatments (Watts, 1992). The accounting choice was developed in response to market-based accounting research (Watts \& Zimmerman, 1986). The theory holds that the need for accounting initially arises because of market imperfections. Complete and perfect markets will mean that there is no demand for accounting disclosure and regulation (Fields, Lys, \& Vincent, 2001). The lack of correlation between the magnitude of expenditure and the value of resulting reserves, as highlighted by Wright and Gallun (2008), underlines the relevance of the accounting choice theory to assessing the SE and FC dilema.

A broad definition of accounting choice is given by Fields, et al (2001):

'An accounting choice is any decision whose primary purpose is to influence (either in form or substance) the output of the accounting system in a particular way, including not only financial statements published in accordance with GAAP but also tax returns and regulatory filings'

Fields, et al (2001) further explains three dimensions to the accounting choice. The first dimension relates to the status and objective of the decision-maker, which brings to the fore the role of the agency and stakeholder theories in explaining why managers make certain choices. The decision-maker, in this respect, may include; regulatory bodies, standard-setting agencies, managers and the national oil (NNPC). The second dimension is in respect of the available alternative choices from which a selection is to be made. SE and FC methods of accounting represent the choices in the context of oil and gas exploration. The implication is that the decision-maker must choose either to capitalize or expense exploration and evaluation costs. The third aspect of the accounting choice theory follows in the argument by Watts (1992) for the need to establish a relationship between the choice of accounting method and the accounting numbers in the financial statements.

The requirement to exercise judgement by accounting standards is the primary basis for accounting choices. This is reflected in such situations as choosing between FIFO (First in- First out) and the weighted average cost for inventory valuation, straight-line depreciation and reducing balance methods of depreciation, and the list goes on. Fields et al (2001) argues that although the freedom of exercising judgement has some benefits, there is also a downside to such liberty. Nonetheless, exercising such judgments helps to address the problem of information asymmetries. It is also relevant when alternative accounting methods (such as SE and FC) may not be perfect 
MANAGEMENT SCIENCES

Vol. 11, No. 3, 2021, E-ISSN: 2225-8329 @ 2021 HRMARS

substitutes from an efficient contracting perspective (Watts \& Zimmerman, 1986). Unconstrained accounting choice has a tendency to result in a cost to financial statement users through such practices as earnings management, which involves financial statement preparers communicating self-serving information at the expense of other stakeholders (Fields et al., 2001).

The conflicting approaches to standard-setting by the IASB and the FASB have been a major concern, especially to multinationals that have had to contend with preparing financial statements in accordance with two conceptual framework bases. While the IASB is more or less a principles-based framework, allowing for the exercise of judgment; the FASB framework, on the other hand, takes a rules-based approach, with little room for judgment (ICAN, 2014). Even so, both frameworks face the same issues in respect of the choice between SE and FC accounting methods. Furthermore, even though Nigeria aligns with the IASB's framework, a bulk of the oil and gas operations in the country is carried out by multinationals, some of whom align with the FASB's framework.

\section{Qualitative Analysis of Se And Fc Methods of Accounting}

Sponsors and critics of the SE and FC methods of accounting for E\&E cost have put forward varied arguments to buttress their views on the controversy. It will be helpful to codify such arguments. Such an approach will, firstly, allow for a pound for pound assessment of the merits and demerits of both methods for managers and accountants alike. Secondly, it can serve as a resource from which standard-setting bodies like the IASB can benefit in the process of issuing future accounting standards for the oil and gas industry. In addition, such a compilation provides a basis for further detailed research into accounting issues confronting the oil and gas industry. The study adopts qualitative criteria to assess the appropriateness of each of the E\&E accounting methods. 
Table 5: Justification and criticism of Successful efforts method

\begin{tabular}{|c|c|}
\hline Argument for & Argument against \\
\hline \multicolumn{2}{|c|}{ Conceptual criteria } \\
\hline & $\begin{array}{l}\text { 1. Provides opportunities for earnings } \\
\text { management practices. It is possible to } \\
\text { smooth income by adjusting the timing } \\
\text { and extent of exploration expenditures } \\
\text { for discretionary period costs } \\
\text { (Mayanja, 2014). }\end{array}$ \\
\hline & $\begin{array}{l}\text { 2. Does not give an accurate economic } \\
\text { picture of the oil and gas industry. The } \\
\text { risk and costs of exploration are } \\
\text { indispensable in discovering oil and gas } \\
\text { reserves regardless of whether the } \\
\text { results are successful or not. It is } \\
\text { therefore unrealistic to not include all } \\
\text { the cost associated with discovering } \\
\text { reserves (Dyckman, 1979). }\end{array}$ \\
\hline
\end{tabular}

\section{IASB framework criteria}

1. It is a prudent approach to accounting for oil and gas operations. Costs of unsuccessful wells are recognized immediately they occur as losses. Conservatism should take precedence over the matching concept (Mayanja, 2014).

2. The Adoption of IFRS 6 by SE companies does not require any sort of modification to the treatment of E\&E expenses; thus, giving credence to the appropriateness of the method.

\section{Industry-specific criteria}

1. The discovery of a dry hole is a common event across all companies in the industry. There is, therefore, no justification for an alternative method of accounting (FC) for such an event (Deakin, 1979).
1. There is no proper matching of cost and revenues as financial statements reflect a write off of unsuccessful exploration expenses (E\&E) against only a portion of the revenues to which it relates.
1. Due to the high cost and risk of exploration, oil and gas firms may be reluctant to embark on exploration activities, since such cost will impact heavily on the reported earnings if the related exploration is unsuccessful.

2. SE method may lead to reduced competition and subsequent monopolization of the industry. This is because small firms may be driven out 
due to their inability to cushion the effect of writing off huge exploration

Source: Author's compilation (2020) costs that result in unsuccessful wells.

Table 6: Justification and criticism of Full cost method

\begin{tabular}{|c|c|}
\hline Argument for & Argument against \\
\hline \multicolumn{2}{|c|}{ Conceptual } \\
\hline $\begin{array}{l}\text { 1. The search for reserves is the } \\
\text { main business of oil and gas } \\
\text { companies. The cost of } \\
\text { unsuccessful wells is a necessary } \\
\text { cost to discover successful wells. } \\
\text { Thus both costs should be } \\
\text { capitalized (Pruett \& Zante, 2003). } \\
\text { It connotes a demonstration of } \\
\text { substance over form. }\end{array}$ & $\begin{array}{l}\text { 1. It is a means of smoothing the income } \\
\text { of the firm; thus, does not convey } \\
\text { accurate information about the } \\
\text { performance of the firm in the period. } \\
\text { This is likely to mislead investors. } \\
\text { 2. There is a greater error in cost } \\
\text { measurement than under SE. This is } \\
\text { because estimates of reserves for the } \\
\text { calculation of DD\&E are highly } \\
\text { subjective and prone to errors. DD\&E is } \\
\text { always greater under the FC method } \\
\text { (Baker, 1979). }\end{array}$ \\
\hline
\end{tabular}

\section{IASB framework criteria}

1. The fact that IFRS 6 permits the use of a choice between the SE and FC methods is an indication that FC can be relied upon to provide relevant and reliable accounting information.
1. Capitalization of cost of dry wells violates the matching concept. The cost of dry holes do not result in future economic benefits, they are losses (Baker, 1979).

2. Cost of dry wells that have been capitalized is not consistent with the accounting framework. It does not meet the asset definition criteria of the framework. Thus, FC financial statements do not reflect a faithful presentation of operations.

3. The very fact that the provisional IFRS 6 limits the extent of capitalization of $E \& E$ expenses is testimony to the weakness of the FC method.

\section{Industry-specific criteria}

1. FC method is likely to encourage aggressive exploration by companies in the industry since cost and risk of exploration, though high, can be spread over a 
wider cost center and accounting period.

2. Allows for healthy competition between small and large firms. Smaller firms do not have the cushion in their portfolios to absorb the effect of writing off E\&E costs in a single period.

Source: Author's compilation (2020)

\section{Investment Risk Exposure}

A simple frequency count (Table 6) was used to measure the exposure of investors to decision making risk arising from the choice between the successful efforts and Full cost methods of accounting.

Table 7: Frequency count of companies quoted in the oil and gas sub-sector of the Nigerian Stock Exchange (NSE)

\begin{tabular}{lcccc}
\hline & & Downstream & Upstream & Total \\
\hline $\begin{array}{l}\text { Number } \\
\text { companies }\end{array}$ & of & 9 & 3 & 12 \\
Percentage (\%) & 75 & 25 & 100 \\
\hline
\end{tabular}

Source: NSE (2020)

Table 7 shows that only three companies out of a possible 12 quoted on the NSE operate in the upstream sector of the Nigerian oil and gas industry. The implication is that the choice between full cost and successful efforts method is applicable only to $25 \%$ of oil and gas companies listed on the NSE. This represents the extent of exposure of investors in Nigeria to the risk occasioned by the choice between full cost and successful efforts accounting.

\section{Conclusion and Recommendation}

Allegations about undue politicization of the standard-setting process continue to trail attempts by both the FASB and the IASB to harmonize the accounting practice in the oil and gas industry. The question of which accounting method is more appropriate for measuring and presenting E\&E activities continues to be a matter of opinion. However, evidence in literature unravelled by this study suggests that the FC method may have come as an afterthought as a result of the failure of standard-setting bodies to issue timely guidance in respect to the extractive industries. Furthermore, table 7 shows that the FC method, despite its justifications, fundamentally is in conflict with the conceptual framework. A consensus should be reached in order to further the goal of harmonization. The study recommends the successful efforts method over the Full cost method.

The findings of the study imply that while there is a significant difference between full cost and successful efforts accounting, investors within the Nigerian context have low exposure $(25 \%)$ to the risk of misjudgment resulting from the choice between full cost and successful efforts method of accounting. This finding is explained by the fact that the respective alternative accounting treatments are relevant only to the extent to which the firm is involved in upstream oil and gas operations. 
MANAGEMENT SCIENCES

Vol. 11 , No. 3, 2021, E-ISSN: 2225-8329 @ 2021 HRMARS

To further enhance the research in the area of FC and SE accounting, further research should explore the long-run impact of the choice between the two methods on the performance of the firm, as well as, in relation to the practice of earnings management. This will aid in boosting the significance of the discussion both in theory and in practice.

\section{References}

Abushaiba, I. A., \& Eldanfo, I. (2014). Argument of accounting for oil and gas upstream activities. International Journal of Humanities and Management Sciences, 2(3), $120-$ 123.

Baker, C. R. (1979). Defects in full-cost accounting in the petroleum industry. Abacus, 12, 152-158.

Brown, A. M. (2006). The financial milieu of the IASB and AASB. Australian Accounting Review 16(1), 85-95.

Deakin , E. B. (1979). An analysis of differences between non-major Oil firms using Successful Efforts and Full Cost methods. The Accounting Review, 54(4), 722-734.

Dyckman, T. R. (1979). Market effects of the elimination of full cost accounting in the oil and gas industry: Another view. Financial Analysts Journal, 35(3), 75-80.

Fields, T., Lys, T., \& Vincent, L. (2001). Empirical research on accounting choice. Journal of Accounting and Economics(31), 225-307.

Institute of Chartered Accountants of Nigeria. (2014). Advanced taxation. Lagos: Institute of Chartered Accountants of Nigeria.

Institute of Chartered Accountants of Nigeria. (2014). Management, governance and ethics. Berkshire, United Kingdom: Emile Woolf International.

Kaoje, A. N., Sa'ad, S. A., Abubakar, M. Y., \& Bala, S. A. (2016). Comparative analysis of Full cost and Successful efforts accounting methods (A theoretical perspective of upstream oil and gas companies). Nigerian Journal of Management Technology \& Development, 7(1), 88-95.

Luther, R. (1996). The development of accounting regulation in the extractive industries: An international review. The International Journal of Accounting, 31, 67-93.

Mayanja, L. M. (2014). Earnings Quality of the Successful Efforts and Full Costing Accounting. Aberdeen, United Kingdom: Robert Gordon University.

Nichols, L. (2012). Has international oil and gas accounting been politicized? Petroleum Accounting and Financial Management Journal, 31(1), 22-34.

Obara, L. C., \& Nangih, E. (2017). Accounting Practices and Performance of Oil and Gas Industry. International Journal of Academic Research in Accounting, Finance and Management Sciences, 7(2), 215-222.

Pruett, S., \& Zante, N. (2003). Successful Efforts versus Full Cost: A continuing controversy may soon be resolved. The Journal of 21st Century Accounting, 3(1), 1-19.

Umobong, A. A. (2015). Choice of accounting methods and reported earnings by oil and gas producing firms in Nigeria: A critical evaluation of full cost and successful effort methods. Arabian Journal of Business and Management Review, 4(12), 1-8.

Watts, R. L. (1992). Accounting choice theory and market-based research in accounting. British Accounting Review(24), 235-267.

Watts, R. L., \& Zimmerman, J. L. (1986). Positive accounting theory. Englewood Cliffs, New Jersey: Prentice-Hall.

Wright, C. J., \& Gallun, R. A. (2008). Fundamentals of oil and gas accounting (5th ed.). Tulsa, USA: PennWell Corporation. 